\title{
Synthesis of limonene $\beta$-amino alcohol derivatives in support of new antileishmanial therapies
}

\author{
Stela R Ferrarini, Cedric S Graebin, Jones Limberger ${ }^{1}$, Rômulo FS Canto, Daiane O Dias, \\ Ricardo G da Rosa', Maria de Fátima Madeira², Vera L Eifler-Lima/ ${ }^{+}$
}

Laboratório de Síntese Orgânica Medicinal 'Laboratório de Catálise por Metais de Transição, Universidade Federal do Rio Grande do Sul, Av. Ipiranga 2752 sala 705, 90610-000 Porto Alegre, RS, Brasil ²Serviço de Parasitologia Clínica, Instituto de Pesquisa Clínica Evandro Chagas-Fiocruz, Rio de Janeiro, RJ, Brasil

A series of seven limonene $\beta$-amino alcohol derivatives has been regioselectively synthesised in moderate to good yields. Two of these compounds were found to be significantly effective against in vitro cultures of the Leishmania (Viannia) braziliensis promastigote form in the micromolar range. The activities found for $3 b$ and $3 f$ were about 100-fold more potent than the standard drug, Pentamidine, in the same test, while limonene did not display any activity. This is the first report of antileishmanial activity by limonene $\beta$-amino alcohol derivatives.

Key words: limonene - $\beta$-amino alcohol - synthesis - leishmaniasis - Leishmania braziliensis - neglected diseases

Parasitic diseases are the cause of much suffering and death throughout the world, mainly in underdeveloped areas like Africa, Asia and Latin America. In these regions, the economic and social impacts caused by these sicknesses are very high because the parasites infect millions of people. Among these parasites, the Protozoa genera are responsible for the principal sicknesses, and leishmaniasis is one of the strictest parasitic diseases caused by multiple species of Leishmania (WHO 2008). The disease is endemic in tropical regions, affecting over 12 million people in 88 countries and its clinical manifestations can occur in cutaneous, mucocutaneous and visceral forms (Croft \& Yeardley 2002, Murray et al. 2005). The main health organisations are concerned about these statistics due to the significant number of cases (Nwaka \& Hudson 2006). Despite this, the therapies currently available to treat this illness are deficient and outdated and most present several sideeffects. Moreover, the widespread development of resistance by certain strains of leishmaniasis to antimonial compounds contributes to poor health conditions in underdeveloped countries. Chemotherapy of leishmaniasis (Croft \& Yeardley 2002, Nwaka \& Hudson 2006) consists of using intravenous drugs like antimonial compounds as first-choice drugs and amphotericine B as second-choice. In countries where many resistance cases to the antimonial drugs are reported, this antibiotic is

Financial support: CAPES/MEC, CNPq, MCT/CNPq 02/2006 Universal (Proc. 483674/2006-0).

+ Corresponding author: veraeifler@ufrgs.br

Received 24 June 2008

Accepted 11 November 2008 used as a first-choice. Intramuscular Pentamidine is administrated in patients infected with Leishmania panamensis and Leishmania braziliensis. Miltefosine and fluconazole are currently the only effective oral treatments for leishmaniasis. However, all of these treatments have significant drawbacks in terms of route of administration, length of treatment (21-28 days), toxicity and cost, which limit their use in endemic areas (Croft \& Yeardley 2002, DNDI 2003, Murray et al. 2005). These arguments by themselves justify the search for new leishmanicidal drugs, which makes the search for new agents a priority for its erradication. In this context, the strategy of following new leads to treat neglected diseases starting from natural sources is widely used by medicinal chemists (Viegas et al. 2006, Newman \& Cragg 2007).

Limonene is a main constituent of essential oils of citrus plants, is abundant in nature and is available in both enantiomeric forms, $R(+)$-limonene la and $S(-)$-limonene $1 \mathrm{~b}$ (Fig. 1). The literature describes some pharmacological activities attributed to essential oils, including antimalarial (Lopes et al. 1999, Tchoumbougnang et al. 2005), antibacterial, antifungal (Filipowicz et al. 2003, Nostro et al. 2004) and antileishmanial (Ueda-Nakamura et al. 2006) effects. For limonene, some activities have been reported as antiproliferative (Crowell et al. 1991) and antimalarial (Moura et al. 2001). In addition, limonene and some of its derivatives have important roles in the cosmetic industry (Deans \& Ritchie 1987, Kim et al. 1995, Beletti et al. 2004). Their use as a building block or a chiral auxiliary in asymmetric synthesis is also well established (Wender et al. 2001, Mehta \& Shinde 2003, Srikrishna \& Dethe 2003, Tokyatsu et al. 2003). Due to the chemical and biological versatility of limonene, it can be employed as a building block for searching for new hits. Its antimalarial activity in vitro has been demonstrated by some sulphone endoperoxide limonene derivatives (Bachi et al. 1998) and antiproliferative activity was detected for new limonene derivatives with a substituted thiourea moiety (Figueiredo et al. 2006). 


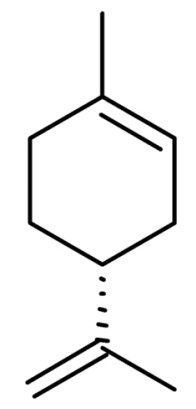

$\mathrm{R}(+)$-limonene

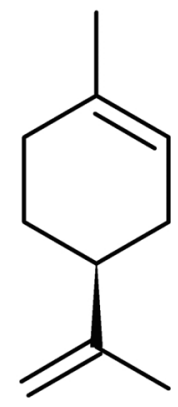

S(-)-limonene
1

Fig. 1: chemical structures for both enantiomers of limonene.

In a previous work, we described the selective chemical modulation of the limonene isoprene group with the synthesis of a set of $N$-alkyl $/ N$-aryl amines through a tandem hydroformilation/reductive amination reaction (Graebin et al. 2008). In the present work, we reported the synthesis of limonene $\beta$-amino alcohols through a regioselective limonene-oxide aminolysis by $N$-alkyl and $N$-aryl amines and their in vitro antileishmanial promastigote activity. $\beta$-amino alcohols are an important class of organic compounds due to their common occurrence in nature and because they are versatile building blocks in the synthesis of a wide range of natural and synthetic products. We have used alkylated amines ( $n$ propylamine, allylamine, ethanolamine, benzylamine), diamine (putrescine), cyclic amine (morpholine) and an aromatic one (aniline) in order to generate diversity at the structure, since for all cases founded in the literature, derivatives with a nitrogen and oxygen heteroatom were more active than limonene.

\section{MATERIAL AND METHODS}

General method to synthesise the amino alcohols 1-methyl-2-(allylamino)-4-isopropenyl-cyclohexanol 3a: $R(+)$-limonene oxide 6 (19.7 mmoles), water $(0.55 \mathrm{~mL})$ and allylamine (56.4 mmoles) were added to a glass beaker and heated for $24 \mathrm{~h}$ under magnetic stirring at $100^{\circ} \mathrm{C}$. The product was purified by acid-base extraction, treated with $\mathrm{CaCl}_{2}$ and dried in a rotator evaporator. Yield $=78 \%$. FTIR (neat, $\mathrm{cm}^{-1}$ ): 3394, 3082, 2937, 1643, 1454. Mass spectrometry $(\mathrm{M} / \mathrm{z}$, rel. abundance in \%): $209(\mathrm{M}+, 0.83) .{ }^{1} \mathrm{H}-\mathrm{NMR}\left(\mathrm{CDCl}_{3}\right): 1.2(3 \mathrm{H}, \mathrm{s}), 1.5(3 \mathrm{H}$, m), $1.7(2 \mathrm{H}, \mathrm{s}), 1.85(3 \mathrm{H}, \mathrm{s}), 2.0(2 \mathrm{H}, \mathrm{m}), 2.2(2 \mathrm{H}, \mathrm{s}), 2.55$ $(1 \mathrm{H}, \mathrm{m}), 3.15(1 \mathrm{H}, \mathrm{dd}, \mathrm{Ja}=15 \mathrm{~Hz}, J \mathrm{~b}=7.5 \mathrm{~Hz}), 3.35(1 \mathrm{H}$, $\mathrm{dd}, J \mathrm{a}=15 \mathrm{~Hz}, J \mathrm{~b}=7.5 \mathrm{~Hz}), 4.8(2 \mathrm{H}, \mathrm{s}), 5.1(1 \mathrm{H}, \mathrm{m}), 5.25$ $(1 \mathrm{H}, \mathrm{m}), 5.9(1 \mathrm{H}, \mathrm{m}) .{ }^{13} \mathrm{C}-\mathrm{NMR}: 22,25,26,30,34,38,51$, 61, 72, 108, 116, 138, 148.

1-methyl-2-(n-propylamino)-4-isopropenyl-cyclohexanol $3 b-{ }^{1} \mathrm{H}-\mathrm{RMN}\left(\mathrm{CDCl}_{3}\right): 0.9(\mathrm{t}, 3 \mathrm{H}, J=7.4 \mathrm{~Hz}), 1.2$ $(\mathrm{s}, 3 \mathrm{H}), 1.5(\mathrm{~m}, 4 \mathrm{H}), 1.7(\mathrm{~s}, 3 \mathrm{H}), 1.98(\mathrm{~m}, 2 \mathrm{H}), 2.45(\mathrm{~m}$, 1H), $2.5(\mathrm{~m}, 1 \mathrm{H}), 2.6(\mathrm{~m}, 4 \mathrm{H}), 4.8(\mathrm{~s}, 2 \mathrm{H}) .{ }^{13} \mathrm{C}-\mathrm{RMN} 11.7$, 21.5, 23.4, 25.5, 34.4, 37.9, 50.0, 61.7, 71.9, 109.2, 148.4 . 1-methyl-2-(ethanolamino)-4-isopropenyl-cyclohexanol $3 c-{ }^{1} \mathrm{H}-\mathrm{RMN}\left(\mathrm{CDCl}_{3}\right): 1.2(\mathrm{~s}, 3 \mathrm{H}), 1.58(\mathrm{~m}, 4 \mathrm{H}), 1.7(\mathrm{~s}$, $3 \mathrm{H}), 1.8(\mathrm{~m} \mathrm{2H}), 2.1(\mathrm{~m}, 1 \mathrm{H}), 2.59(\mathrm{~m}, 1 \mathrm{H}), 2.66(\mathrm{~m}, 2 \mathrm{H})$, $2.85(\mathrm{~m}, 2 \mathrm{H}), 4.7$ (s, $1 \mathrm{H}), 4.8(\mathrm{~s}, 1 \mathrm{H}) .{ }^{13} \mathrm{C}-\mathrm{RMN}: 21.5,25.9$, 30.2, 34.7, 37.9, 49.3, 60.9, 61.4, 72.0, 109.5, 148.3 .

1-methyl-2-N-(1,4-diaminobutane)-4-isopropenylcyclohexanol $3 d-{ }^{1} \mathrm{H}-\mathrm{RMN}\left(\mathrm{CDCl}_{3}\right): 1.2(\mathrm{~s}, 3 \mathrm{H}), 1.47$ $(\mathrm{m}, 4 \mathrm{H}), 1.50(\mathrm{~m}, 4 \mathrm{H}), 1.7(\mathrm{~s}, 3 \mathrm{H}), 1.95(\mathrm{~m}, 2 \mathrm{H}), 2.1(\mathrm{~m}$, $1 \mathrm{H}), 2.15(\mathrm{~m}, 1 \mathrm{H}), 2.47(\mathrm{~m}, 1 \mathrm{H}), 2.69(\mathrm{~m}, 4 \mathrm{H}), 4.7(\mathrm{~s}, 1 \mathrm{H})$, 4.8 (s, 1H). ${ }^{13} \mathrm{C}-\mathrm{RMN}: 21.5,25.9,27.6,30.1,31.0,34.6$, 37.9, 41.7, 47.8, 61.7, 71.9, 109.3, 148.4 .

1-methyl-2-(N-morpholino)-4-isopropenyl-cyclohexanol $3 e-{ }^{1} \mathrm{H}-\mathrm{RMN}\left(\mathrm{CDCl}_{3}\right)$ : $1.1(\mathrm{~s}, 3 \mathrm{H}), 1.48(\mathrm{~m}, 4 \mathrm{H})$, $1.7(\mathrm{~s}, 3 \mathrm{H}), 1.95(\mathrm{~m} \mathrm{1H}), 2.0(\mathrm{~m}, 2 \mathrm{H}), 2.4(\mathrm{~m}, 5 \mathrm{H}), 3.6(\mathrm{~m}$, 4H), 4.7 (s, 1H), 4.8 (s, 1H). ${ }^{13} \mathrm{C}-\mathrm{RMN}: 22.1,22.3,24.4$, 24.8, 35.5, 38.8, 51.9, 67.3, 67.4, 72.6, 110.9, 145.3.

1-methyl-2-(N-phenylamino)-4-isopropenyl-cyclohexanol $3 f-{ }^{1} \mathrm{H}-\mathrm{RMN}\left(\mathrm{CDCl}_{3}\right): 1.2(\mathrm{~s} 3 \mathrm{H}), 1.7(\mathrm{~s}, 3 \mathrm{H})$, $1.62(\mathrm{~m}, 1 \mathrm{H}), 1.93(\mathrm{~m}, 2 \mathrm{H}), 2.1(\mathrm{~m}, 1 \mathrm{H}), 3.49(\mathrm{~m}, 1 \mathrm{H}), 4.7$ $(\mathrm{s}, 2 \mathrm{H}), 6.9(\mathrm{~m}, 3 \mathrm{H}), 7.1(\mathrm{~m}, 2 \mathrm{H}),{ }^{13} \mathrm{C}-\mathrm{RMN}: 21.3,26.1$, $31.3,34.4,38.9,57.6,72.4,110.0,112.6,147.6$, 148.8, 116.9, 118.8 .

1-methyl2-(N-benzylamino)-4-isopropenyl-cyclohexanol $3 g-{ }^{1} \mathrm{H}-\mathrm{RMN}\left(\mathrm{CDCl}_{3}\right): 1.1(\mathrm{~s}, 3), 1.58(\mathrm{~m}, 2 \mathrm{H}), 1.7$ $(\mathrm{s}, 3 \mathrm{H}), 1.86(\mathrm{~m}, 2), 2.15(\mathrm{~m}, 1 \mathrm{H}), 2.5(\mathrm{~m}, 1 \mathrm{H}), 4.8(\mathrm{~s}, 2 \mathrm{H})$, $3.67(\mathrm{~m}, 1 \mathrm{H}), 3.85(\mathrm{~m}, 1 \mathrm{H}), 7.27$ (s, 5H). ${ }^{13} \mathrm{C}-\mathrm{RMN}: 21.4$, 26.1, 30.0, 34.4, 37.9, 52.1, 61.2, 72.0, 109.3, 126.9, 128.1, $128.5,140.7,148.7$.

7-allyl-4-isopropenyl-1-methyl-7-azabicycle [4.1.0]heptane 4 - A solution of 9.58 mmols of $\mathrm{PPh}_{3} \mathrm{Br}_{2}$ in acetonitrile was added drop wise over a solution of 9.58 mmols of $3 \mathrm{a}$ in an ice bath with magnetic stirring. Then triethylamine $(14.2 \mathrm{mmol})$ was added, and the reaction was stirred for an additional $5 \mathrm{~min}$, after which the reaction mixture was decanted for $24 \mathrm{~h}$. The liquid phase of the mixture was filtered with Celite and the resulting clear orange solution was dried in a rotary evaporator. The solid residue was treated with hexane, the organic layer was dried with a rotatory evaporator and the oily residue of this evaporation was purified by column chromatography, using hexane/ethyl acetate $(6: 1)$ as the eluent. Yield $=40 \%$. Mass spectrometry $(\mathrm{M} / \mathrm{z}$, rel. abundance in \%): $191(\mathrm{M}+, 1.67) .{ }^{1} \mathrm{H}-\mathrm{NMR}\left(\mathrm{CDCl}_{3}\right)$ : $1.15(1 \mathrm{H}$, m), $1.22(3 \mathrm{H}, \mathrm{s}), 1.5(2 \mathrm{H}, \mathrm{m}), 1.7(3 \mathrm{H}, \mathrm{s}), 1.76(3 \mathrm{H}, \mathrm{m})$, $1.85(1 \mathrm{H}, \mathrm{m}), 2.03(1 \mathrm{H}, \mathrm{dd}, \mathrm{Ja}=17 \mathrm{~Hz}, J \mathrm{~b}=4.3 \mathrm{~Hz}), 3.08$ $(2 \mathrm{H}, \mathrm{m}), 4.7(2 \mathrm{H}, \mathrm{dd}, J \mathrm{a}=17.6 \mathrm{~Hz}, J \mathrm{~b}=2.1 \mathrm{~Hz}), 5.1(1 \mathrm{H}$, $\mathrm{dq}, J \mathrm{a}=17.1 \mathrm{~Hz}, J \mathrm{~b}=2.1 \mathrm{~Hz}), 5.25(1 \mathrm{H}, \mathrm{dq}, J \mathrm{a}=17.1 \mathrm{~Hz}$, $J \mathrm{~b}=2.1 \mathrm{~Hz}), 5.95(1 \mathrm{H}, \mathrm{m}, J=4.7 \mathrm{~Hz}) .{ }^{13} \mathrm{CNMR}: 18,21$, 26, 30, 33, 37, 38, 46, 55, 109, 117, 137, 150.

Leishmanicidal assay - This assay was performed as described by Machado et al. (2007). Cultures of L. (Viannia) braziliensis (MCAN/BR/98/R.619) were maintained in Schneider's Drosophila medium ( $\mathrm{pH} 7.2)$ with foetal bovine serum $(10 \%)$ at $26^{\circ} \mathrm{C}$ and on the fourth day of growth, the culture was sedimented by centrifugation (10 $\left.\mathrm{min}, 4^{\circ} \mathrm{C}, 4000 \mathrm{rpm}\right)$, suspended in $1 \mathrm{~mL}$ of the same medium and quantified in a Neubauer chamber. Enough medium was added in order to adjust the parasitic concen- 
tration to $2 \times 10^{6}$ promastigotes $/ \mathrm{mL}$. The determination of the leishmanicidal activity was performed in 96-well plates. The compounds were tested in triplicate in a concentration gradient from $320-0.156 \mu \mathrm{g} / \mathrm{mL}$. The parasitic concentration in the wells was of $2 \times 10^{5}$ promastigotes/ $\mathrm{mL}$. A negative control was performed with three wells containing only parasites and the incubation medium. The positive control was made with Pentamidine isothionate $(320 \mu \mathrm{g} / \mathrm{mL})$. After $24 \mathrm{~h}$ of incubation at $26^{\circ} \mathrm{C}, 10 \mu \mathrm{L}$ of each well was diluted in $90 \mu \mathrm{L}$ of the vital colorant (trypan blue in PBS) and the parasites were quantified in a Neubauer chamber. The data obtained from this quantification were plotted in a graph using Microsoft Excel and the $\mathrm{LD}_{50}$ was extrapolated from the graph as the concentration of the products that inhibited the parasitic growth at $50 \%$ of the values of the negative control.

Relative toxicity assay - The cytotoxic effect of the compounds described in this paper was evaluated in murine peritoneal macrophages using 3-(4,5-dimethylthiazol-2-yl)-2,5-diphenyl-tetrazoliumbromide(MTT) in a colourimetric assay as previously reported (Mosmann 1983). Briefly, the cells were isolated from the peritoneal cavity of mice and, after adjusting the cell concentration to $4 \times 10^{5}$ cells $/ \mathrm{mL}$ of medium, the cells were cultivated on a 96-well microtitre plate with RPMI medium, supplemented with $10 \%$ of foetal calf serum and incubated at $37^{\circ} \mathrm{C}$ in a humidified atmosphere with $5 \% \mathrm{CO}_{2}$. The compounds were added in triplicate to the cell culture at the respective $\mathrm{LD}_{50}$ concentrations. Three wells of the cell culture, without adding any compound, were used as controls. The plate was then incubated in the same conditions as described above for $24 \mathrm{~h}$. Then, $22 \mu \mathrm{L}$ of an MTT solution $(5 \mathrm{mg} / \mathrm{mL})$ was added to each well and the plate was further incubated for $3 \mathrm{~h}$. The enzymatic reaction was stopped with addition of $80 \mu \mathrm{L}$ of DMSO, the plate was gently shaken at rt for $15 \mathrm{~min}$ and the optical density was read in a spectrophotometer (492 $\mathrm{nm})$. The toxicity was expressed as a relative value, using the optical density of the control wells as a reference.

\section{RESULTS AND DISCUSSION}

Aminolysis is a classical route for the preparation of $\beta$-amino alcohols from epoxides, and a large excess of amines is typically used, leading to products with moderate or low yields. In this paper, we have employed the $R$ $(+)$-limonene oxide 2 stirred with one equivalent of amine (except for aniline, where it was necessary to use 2 equivalents) and three equivalents of water at reflux for $24 \mathrm{~h}$ to prepare the $\beta$-amino alcohols 3a-3g (Fig. 2) in moderate to good yields, as highlighted in Table I, according to a previously reported chemical pathway (Chrisman et al. 2001). Three of these molecules are new: $3 \mathrm{a}, 3 \mathrm{c}$ and $3 \mathrm{~d}$ (Kozhin et al. 1978, Chrisman et al. 2001, Singaram et al. 2002, Steiner et al. 2002). The $R$-(+)-limonene oxide 2 was chosen as the starting material because it is readily available and inexpensive. Moreover, the synthesis of this epoxide from limonene (Jones et al. 1999) would add an avoidable step to the synthetic pathway. The original aziridine 4 was obtained from $3 \mathrm{a}$ in the presence of $\mathrm{PPh}_{3} \mathrm{Br}_{2}$ under basic conditions. The compounds were purified and characterised by classical analytic methods.
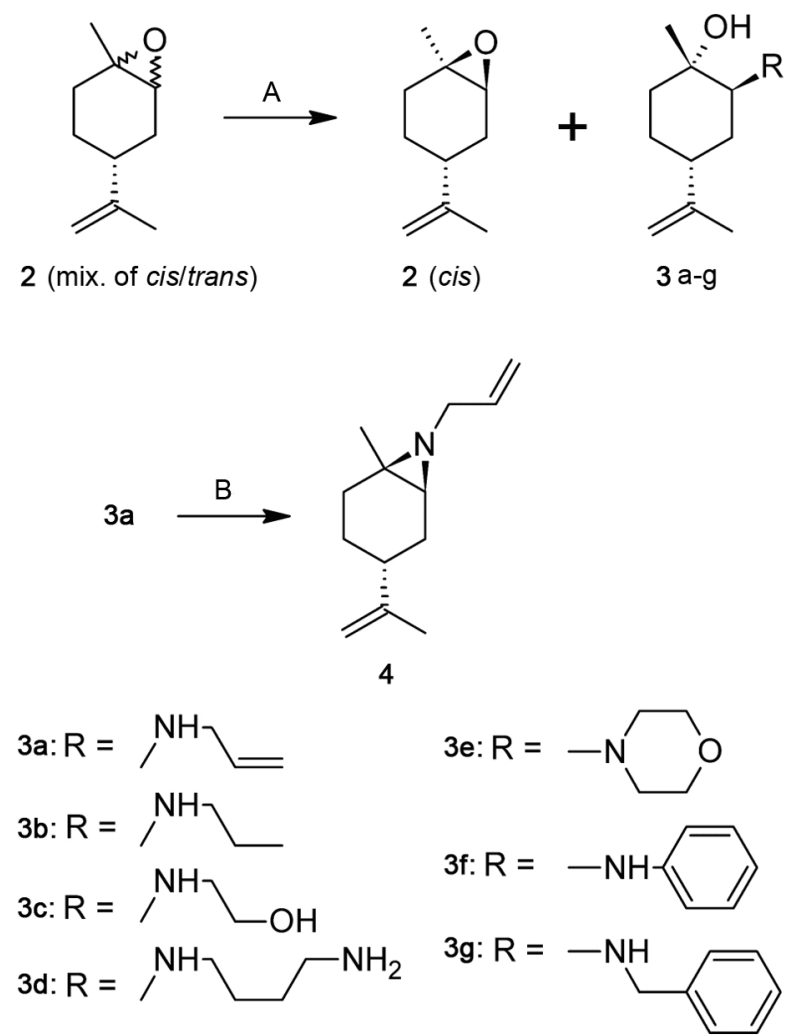

Fig. 2: conditions: A: amine (2 equiv.), $\mathrm{H}_{2} \mathrm{O}$ (3 equiv.), $80^{\circ} \mathrm{C}, 24 \mathrm{~h}$; $\mathrm{B}: \mathrm{PPh}_{3} \mathrm{Br}_{2}$ in acetonitrile, rt, then triethylamine, $5 \mathrm{~min}$, rt.

\section{TABLE I}

Aminolysis reaction of $R-(+)$-limonene oxide 2 (cis and trans mixture) with several amines

\begin{tabular}{lccc}
\hline Amine & ${\text { Yield }(\%)^{a}}^{a}$ & Trans $(\%)^{b}$ & cis $(\%)^{b}$ \\
\hline Allylamine & 78 & 85 & 15 \\
Propilamine & 48 & 100 & - \\
Etanolamine & 68.5 & 82 & 18 \\
Putrescine & 62.5 & 69 & 31 \\
Morpholine & 56.9 & 95 & 5 \\
Aniline & 48 & 94 & 6 \\
Benzylamine & 21 & 100 & - \\
\hline
\end{tabular}

$a$ : calculated by the consumption of limonene oxide in the gas chromatogram (GC), using triethylamine as a internal standard; $b$ : according to the GC data.

It is known that, due to conformation of the ring of limonene oxide, the aminolysis is regioselective, leading only to the trans regioisomer (Chrisman et al. 2001, Singaram et al. 2002). The conditions carried out in this work allow for a regioselective ring opening resulting in $\beta$-amino alcohols with a trans conformation as the only or major product, which was attributed by NMR and $\mathrm{CG}$ analyses. For example, the ${ }^{1} \mathrm{H}-\mathrm{NMR}$ spectrum of $3 \mathrm{a}$ demonstrates additional peaks attributed to 
$\mathrm{NH}$-allyl and to $\mathrm{OH}$ groups at $\delta=3.25 \mathrm{ppm}$. For the vicinal amino alcohol 3f, we can detect the additional peaks corresponding to the NH-phenyl unit and the $\mathrm{OH}$ group at $\delta=3.9 \mathrm{ppm}$ and to the aromatic protons at $\delta=6.6$ and $7.1 \mathrm{ppm}$. The selectivity of this reaction can be explained by the conformational differences between cis and trans diastereomers (Steiner et al. 2002). Concerning the trans isomer, the ring opening by the amines occurs mainly on the less hindered side of the epoxide, via a transition state that is thermodynamically more stable in a chair conformation. The boat conformation is not so energetically favored, and the cis epoxide can be recovered at the end of the reaction. The aziridine 4 was obtained from the reaction of $3 \mathrm{a}$ with $\mathrm{PPh}_{3} \mathrm{Br}_{2}$ and triethylamine (Fig. $2)$. The ${ }^{1} \mathrm{H}-\mathrm{NMR}$ spectra show that the two vinylic protons of the isopropenyl group remain untouched at $\delta=$ $4.7 \mathrm{ppm}$. The three new allylic protons at $\delta=5.10,5.25$ and $5.95 \mathrm{ppm}$ and the two methyl groups appear as singlets, such that one is in the isopropenyl portion of the molecule at $\delta=1.7 \mathrm{ppm}$ and the other one is close to the aziridine cycle at $1.21 \mathrm{ppm}$.

Leishmanicidal activity was determined and, according to the data highlighted in Table II, among the seven $\beta$-amino alcohols tested, two of these were more active than Pentamidine $(48.5 \pm 28.7 \mu \mathrm{M})$ and five were more active than limonene 1a. In fact, the $(R)$-limonene 1a was inactive in the test $(876.2 \pm 216 \mu \mathrm{M})$, showing that this terpene, when isolated, is not active against promastigotes of L. braziliensis. The derivatives $n$-propyl $3 \mathrm{f}$ $(0.408 \pm 0.02)$ and phenyl $3 \mathrm{~b}(0.71 \pm 0.095 \mu \mathrm{M})$ exhibited more powerful activities. The lipophilic character of the substituents seems to be required in order to interact with the parasite. We can clearly observe this, since, when the activity of the compounds decreases, the polarity increases. The $\beta$-amino alcohols $3 \mathrm{f}$ and $3 \mathrm{~b}$ bearing the hydrophobic substituents phenyl and $n$-propyl groups were more active $(0.408 \pm 0.01 \mu \mathrm{M}$ and $0.71 \pm 0.095 \mu \mathrm{M}$,

\section{TABLE II}

\begin{tabular}{|c|c|c|}
\hline Tompound & $\mathrm{LD}_{50}(\mu \mathrm{M})^{a}$ & Rel. toxicity (\%) $)^{a, b}$ \\
\hline & $510.0 \pm 92.5$ & $17.1 \pm 1.97$ \\
\hline$a$ & $76.5 \pm 13.9$ & $0.33 \pm 2.57$ \\
\hline b & $0.71 \pm 0.095$ & $4.99 \pm 3.64$ \\
\hline c & $1042.6 \pm 65.2$ & $22.34 \pm 1.14$ \\
\hline d & $>1330$ & $c$ \\
\hline e & $>1333$ & $c$ \\
\hline$f$ & $0.408 \pm 0.01$ & $4.52 \pm 1.71$ \\
\hline g & $830.7 \pm 185$ & $35.37 \pm 2.26$ \\
\hline & $876.2 \pm 216$ & $14.36 \pm 2.32$ \\
\hline entamidine & $48.5 \pm 28.7$ & $35.51 \pm 2.72$ \\
\hline
\end{tabular}

$a$ : values are means \pm standard deviation of three experiments; $b$ : toxicity of the compounds at their $\mathrm{LD}_{50}$ concentrations in a cell culture of murine peritoneal macrophages, relative to a control culture; $c$ : not determined. respectively), while compound $3 \mathrm{a}$ carrying the allyl moiety presented approximately the same potency of Pentamidine $(76.5 \pm 13.9 \mu \mathrm{M})$. The replacement of the lipophilic aliphatic amines by more polar amines resulted in a dramatic decrease in activity as well. The three less active derivatives were $3 \mathrm{~d}$ with the putrescine chain, $3 \mathrm{e}$ with the morpholine ring and $3 \mathrm{c}$ with ethanolamine, showing no activity at the highest concentration used in the test.

The substituent volume is another important aspect, since the compound $3 \mathrm{~g}$ bearing a benzylamine moiety $(830.7 \pm 185 \mu \mathrm{M})$ was much less active than the $\beta$-amino alcohol $3 f$ carrying the aniline $(0.408 \pm 0.01 \mu \mathrm{M})$. It was also observed that the allylaziridine 4 presented low performance at the same test $(510.00 \pm 92.5 \mu \mathrm{M})$. Taking into account the result obtained with $3 \mathrm{a}$, the conformational modifications on the cyclohexane ring of 4 caused by the additional aziridine nucleus, which forms a new bicyclic strained system, can be responsible for the decrease in activity. Future investigations must be performed in order to clarify this lack of activity.

The results obtained with this work are preliminary and can neither establish a Structure-Activity Relationship study of compounds nor speculate about the mechanism of action. However, they characterise the introduction of a heteroatom such as nitrogen in the limonene core, showing that it leads to compounds with promising leishmanicidal activity.

The toxicity assay results, expressed in Table II, show that compounds $3 \mathrm{a}, 3 \mathrm{~b}$ and $3 \mathrm{f}$ presented low toxicity when compared to the control cell cultures. These three compounds have lower toxicity values than the standard drug used in the leishmanicidal assay, Pentamidine $(35.51 \pm 2.52 \%)$ and the terpene $R$ - $(+)$-limonene 1a $(14.36 \pm 2.32 \%)$, while compounds $3 \mathrm{c}, 3 \mathrm{~g}$ and 4 showed moderated toxicity values. Due to their high $\mathrm{LD}_{50}$ values, compounds $3 \mathrm{~d}$ and $3 \mathrm{e}$ were not employed in this assay.

In conclusion, we have demonstrated the in vitro activity of a new class of $\beta$-amino alcohol derivative using $R(+)$-limonene as a building block against the $L$. braziliensis promastigote. The results obtained in this series demonstrate that limonene is a good scaffold for the design and synthesis of new $\beta$-amino alcohols intended to search for new hits for this parasite. The two most active compounds in the leishmanicidal assay (3b and $3 \mathrm{f}$ ) showed low in vitro toxicity values against a murine macrophage culture. The results are preliminary, but they provide a starting point to design other modifications from the limonene architecture in order to guide further structure activity-relationship studies. The use of an economical and largely available natural product to generate biologically active compounds requiring few synthetic steps is an attractive strategy to discover new lead candidates. As such, studies are currently underway to investigate the mechanism of action for the antileishmanial activity observed here, and these findings will be reported elsewhere.

\section{ACKNOWLEDGMENTS}

To Dr. Hugo Verli (UFRGS), for facilitating the first contact between our research groups. 


\section{REFERENCES}

Bachi MD, Korshin EE, Ploypradith P, Cumming JN, Xie S, Shapiro TA, Posner GH 1998. Synthesis and in vitro antimalarial activity of sulfone endoperoxides. Bioorg Med Chem Lett 8: 903-908.

Belletti N, Ndagijimana M, Sisto C, Guerzoni ME, Lanciotti R, Gardini F 2004. Evaluation of the antimicrobial activity of citrus essences on Saccharomyces cerevisiae. J Agric Food Chem 52: 6932-6938.

Chrisman W, Câmara JN, Marcellini K, Singaram B, Goralski CT, Hasha DL, Rudolf, PR, Nicholson LW, Borodychuk KK 2001. A simple and convenient synthesis of $\beta$-amino alcohol chiral auxiliaries based on limonene oxide. Tetrahedron Lett 42: 5805-5807.

Croft SL, Yeardley V 2002. Chemotherapy of Leishmaniasis. Curr Pharm Design 8: 319-342.

Crowell PL, Chang RR, Ren Z, Elson CE, Gould MN 1991. Selective inhibition of isoprenylation of $21-26-\mathrm{kDa}$ proteins by the anticarcinogen d-limonene and its metabolites. J Biol Chem 266: 17679-17685.

Deans SG, Ritchie G 1987. Antibacterial properties of plant essential oils. Intl J Food Microbiol 5: 165-180.

DNDI - Drugs for Neglected Diseases Initiative 2003. Avaliable from: http://www.dndi.org [cited 2008 May 15].

Figueiredo IM, Santos LV, Costa WF, Carvalho JE, Silva CC, Sacoman JL, Kohn KL, Sarragiotto MH 2006. Synthesis and antiproliferative activity of novel limonene derivatives with a substituted Thiourea Moiety. J Braz Chem Soc 17: 954-960.

Filipowicz N, Kaminski M, Kurlenda J, Asztemborska M, Ochocka JR 2003. Antibacterial and antifungal activity of juniper berry oil and its selected components. Phytother Res 17: 227-231.

Graebin CS, Eifler-Lima VL, Rosa RG 2008. One-pot synthesis of secondary and tertiary amines from $R(+)$-limonene by tandem hydroformylation/reductive amination (hydroaminomethylation). Catal Comm 9: 1066-1070.

Jones J Jr, Kover RX, Kover WB, Castro FL 1999. A Novel synthesis of 1-Acetyl-4-Isopropenyl-1-Cyclopentene by chemoselective cyclization of 4-Methyl-3-(Oxobutyl)-4-Pentenal: an important intermediate for natural product synthesis. J Braz Chem Soc 10: $112-116$.

Kim J, Marshall MR, Wei C 1995. Antibacterial activity of some essential oil components against five foodborne pathogens. J Agric Food Chem 43: 2839-2845.

Kozhin SA, Zaitsev VV, Ionin BI 1978. Aminolysis products of 1,2-mono-epoxy limonene. Zh Obshch Khim 48: 203-217.

Lopes NP, Kato MJ, Andrade EHA, Maia JGS, Yoshida M, Planchart AR, Katzin AM 1999. Antimalarial use of volatile oil from leaves of Virola surinamensis (Rol.) Warb. by Waiãpi Amazon Indians. J Ethnopharmacol 67: 313-319.

Machado GMC, Leon LL, Castro SL 2007. Activity of Brazilian and Bulgarian propolis against different species of Leishmania. Mem Inst Oswaldo Cruz 102: 73-77.
Mehta G, Shinde HM 2003. Enantiospecific total synthesis of 6-epi$(-)$-hamigeran B. Intramolecular Heck reaction in a sterically constrained environment. Tetrahedron Lett 44: 7049-7053.

Mosmann T 1983. Rapid colorimetric assay for cellular growth and survival: application to proliferation and cytotoxicity assays. Journal of Immunol Methods 65: 55-63.

Moura IC, Wunderlich G, Uhrig ML, Couto AS, Peres VJ, Katzin AM, Kimura AE 2001. Limonene arrests parasite development and inhibits isoprenylation of proteins in Plasmodium falciparum. Antimicr Ag Chemother 45: 2553-2558.

Murray HW, Berman JD, Davies CR, Saravia NG 2005. Advances in leishmaniasis. Lancet 366: 1561-1577.

Newman D, Cragg GM 2007. Natural products as sources of new drugs over the last 25 years. J Nat Prod 70: 461-477.

Nostro A, Blanco AR, Cannatelli MA, Enea V, Flamini G, Morelli I, Roccaro AS, Alonzo V 2004. Susceptibility of methicillin-resistant staphylococci to oregano essential oil, carvacrol and thymol. FEMS Microbiology Lett 230: 191-195.

Nwaka S, Hudson A 2006. Innovative lead discovery strategies for tropical diseases. Nature Rev Drug Disc 5: 941-955.

Singaram B, Chrisman W, Goralski CT 2002. Chiral amino alcohols and process for preparation of same. World Patent WO0222550. Avaliable from http://www.wipo.int/pctdb/en/wo.jsp?wo=2002022550.

Srikrishna A, Dethe DH 2003. Enantiospecific first total synthesis and assignment of absolute configuration of the sesquiterpene (-)-Cucumin H. Org Lett 5: 2295-2298

Steiner D, Sethofer SG, Goralski CT, Singaram B 2002. Asymmetric addition of diethylzinc to aldehydes catalyzed by $\beta$-amino alcohols derived from limonene oxide. Tetrahedron: Asymmetry 13: $1477-1483$

Tchoumbougnang F, Zollo PHA, Dagne E, Mekonnen Y 2005. In vivo antimalarial activity of essential oils from Cymbopogon citratus and Ocimum gratissimum on mice infected with Plasmodium berghei. Planta Med 71: 20-23.

Tokuyasu T, Kunikawa S, Abe M, Masuyama A, Nojima M, Kim HS, Wataya Y 2003. Synthesis of antimalarial Yingzhaosu A analogues by the peroxidation of dienes with $\mathrm{Co}(\mathrm{II}) / \mathrm{O}_{2} / \mathrm{Et}_{3} \mathrm{SiH}$. J Org Chem 68: 7361-7367.

Ueda-Nakamura T, Mendonça-Filho RR, Morgado-Díaz JA, Maza PK, Dias Filho BDPAGC, Alviano DS, Rosa MSS, Lopes AHCS, Nakamura CV 2006. Antileishmanial activity of Eugenol-rich essential oil from Ocimum gratissimum. Parasitol Int 55: 99-105.

Viegas C Jr, Bolzani VS, Barreiro EJ 2006. Os produtos naturais e a química medicinal moderna. Quim Nova 29: 326-337.

Wender PA, Bi FC, Brodney MA, Gosselin F 2001. Asymmetric synthesis of the tricyclic core of NGF-inducing cyathane diterpenes via a transition-metal-catalyzed [5+2] cycloaddition. Org Lett 3: 2105-2108

WHO-World Health Organization 2008. Leishmaniasis: Background Information. Avaliable from: http://www.who.int/leishmaniasis/ en [updated 2008 Mar 13; cited 2008 May 15]. 